\title{
Comparison of Effect of Various Types of Soybeans on Mutagenicity and Growth of Human Cancer Cell Lines
}

\author{
Sun-Young Lim* \\ Division of Marine Environment \& Bioscience, Korea Maritime University, Busan 606-791, Korea \\ Received July 28, 2010 / Accepted October 25, 2010
}

\begin{abstract}
This study compared the inhibitory effects of methanol extracts from yellow and black soybeans (black soybean, Seomoktae and Seoritae) on mutagenicity using the Ames test and growth of human cancer cells (AGS human gastric adenocarcinoma, HT-29 human colon cancer, Hep 3B hepatocellular carcinoma cells). In the Ames test system using Salmonella typhimurium TA100, aflatoxin $\mathrm{B}_{1}\left(\mathrm{AFB}_{1}\right)$-induced mutagenicity was significantly inhibited by treatments with the methanol extracts from either yellow or black soybeans in a dose dependent manner $(p<0.05)$. The methanol extracts from various black soybeans tended to have a greater inhibitory effect compared to those from yellow soybeans. As for N-methyl-N'-nitro-N-nitrosoguamidine (MNNG)-induced mutagenicity, the methanol extracts (5 $\mathrm{mg}$ /assay) from black soybean, Seomoktae and Seoritae showed 51\%, 61\% and 53\% inhibitory rates, respectively, indicating that Seomoktae, a type of black soybean, had a stronger antimutagenic activity against mutagens (both $\mathrm{AFB}_{1}$ and $\mathrm{MNNG}$ ). Methanol extracts from black soybeans showed an inhibitory rate of greater than $50 \%$ on the growth of human cancer cells (AGS, HT-29 and Hep 3B) and the inhibition was more effective in the methanol extract from Seomoktae. Our results suggested that the methanol extracts from black soybeans showed stronger inhibitory effects on mutagenicity and growth of cancer cells than those from yellow soybean. It is concluded that intake of black soybean can be recommended for improving health.
\end{abstract}

Key words : Black soybean, antimutagenicity, human cancer cells, Ames test

\section{서 론}

검정콩은 블랙푸드를 대표하는 검은색 식품으로 흑태, 서목 태 및 서리태로 구분한다. 흑태는 보통의 검정콩을 일컬으며 검정콩 가운데서 크기가 가장 크며 맛이 담백하고 고소해 밥 이나 콩조림 등 두루 사용되며 서목태는 검정콩 중에서 크기 가 가장 작고 윤기가 나며 해독작용이 뛰어나 “약콩” 혹은 “쥐눈이콩”이라고 불리고 주로 한방에서 이용된다. 서리태는 첫 서리 내릴 때 따는 콩이라 붙여진 이름으로 껍질은 검은색 이지만 속이 파랗다고 하여 “속청”이라 부리며 고소한 맛이 강하여 콩찰편, 콩자반 및 밥에 넣어 식용된다. <본초강목>에 서 검정콩의 효능에 대하여 "신장을 다스리고 부종을 없애며 혈액순환을 활발하게 하며 모든 약의 독을 풀어준다"고 기록 되어 있다. 우리나라 고유의 검정콩은 예부터 약의 소재로 활 용되어 겨울에 기침이 심할 때 흑두를 삶아 그 즙에다 흑설탕 을 가하여 차대신 수시로 마시면 기침이 멎는다고 하여 많이 음용되었다[9]. 검정콩은 일반콩과 비교하여 노화방지 성분이 4 배나 많고 성인병 예방과 다이어트에 효과가 있다고 알려지 면서 건강식품으로 각광받고 있다[10,17].

검정콩 종실은 일반 노란콩과 성분면에서 큰 차이가 없고

*Corresponding author

Tel : +82-51-410-4757, Fax : +82-51-404-4750

E-mail : sylim@hhu.ac.kr
단지 종피에 anthocyanin이 함유되어 있는 것이 특징이다. Anthocyanin이라는 검정콩 종피의 페놀성 물질은 적색, 자색, 청색을 나타내는 수용성 플라보노이드 색소로 인체에 아무런 부작용이 없고 항산화 효과 등의 생리활성이 높은 것으로 알 려져 있다 $[5,8,20,22]$. 또한 검정콩은 대두보다 많은 isoflavone 을 함유하고 있어 높은 항산화 및 항노화 작용을 하는 것으로 보고되었다[3,7,14,15]. Ryu와 Moon [16]은 검정콩 및 노란콩 섭취에 의한 항노화 효과를 알아보기 위하여 심장과 눈에서 노화측정의 지표인 lipofuscin 생성을 측정한 결과 노란콩 섭 취군과 비교했을 때 검정콩 섭취군에서 높은 저해효과를 나타 내었으며 이는 검정콩 종피에 함유되어 잇는 anthocyanin 색 소에 기인하는 것이라고 보고하였다. Bae와 Moon [2]은 노란 콩, 밤콩, 검정콩, 소립검정콩을 각각 콩전체, 콩껍질과 속으로 분리하여 실험한 결과 콩전체의 경우 노란콩 보다 밤콩, 검정 콩, 소립검정콩 등의 색이 짙은 콩의 항산화 효과가 높았고 이들을 껍질과 속으로 분리하여 항산화 효과를 측정한 결과 콩 속의 항산화 효과는 네 종류의 콩에서 유사한 것으로 나타 났으나 껍질의 경우 노란콩보다 밤콩, 검정콩, 소립검정콩 등 의 색이 짙은 콩껍질에서 높은 항산화 효과를 나타내어서 콩 의 항산화 효과에는 콩껍질에 함유되어 있는 색소물질이 중요 한 역할을 한다고 보고하였다. Son [21] 등은 통풍을 일으키는 원인 물질인 요산을 생성하는 xanthine oxidase에 대한 검정콩 색소의 활성저해능을 측정한 결과 높은 저해활성을 나타내었 
다고 보고하였다. 따라서 본 연구에서는 건강식품으로 각광받 고 있는 검은콩의 생리활성을 노란콩과 비교하고 검정콩에 속하는 흑태, 서목태 및 서리태를 중심으로 Ames 실험을 이용 한 돌연변이 유발 및 인체 암세포 증식 억제 효과에 대해 알아 보고자 한다.

\section{재료 및 방법}

\section{재료}

실험에 사용된 대두(미국산)와 검정콩에 속하는 흑태, 서리 태 및 서목태(국내산)는 부산 부전시장에서 구입하여 세척한 후 동결 건조한 다음 분쇄한 후 각각 5 배의 메탄올을 넣고 3회 추출하였다. 회전식 진공 농축기(Buchi oil \& 461, Switserland)를 이용하여 농축한 후 dimethyl sulfoxide (DMSO)에 녹여 실험에 사용하였다. 세포배양에 사용된 $\mathrm{DMSO}$ 의 최종농도는 $0.1 \%$ 이하가 되도록 하였다.

\section{Ames 돌연변이 유발실험}

Salmonella typhimurium TA100은 S. typhimurium LT-2의 histidine auxotroph로서 미국 California 대학의 B.N. Ames 박사로부터 제공받아 정기적으로 histidine 요구성, deep rough $(r f a)$ 돌연변이, $u v r \mathrm{~B}$ 돌연변이, R factor 등의 유전형질 을 확인하면서 실험에 사용하였다. 간접 돌연변이 유발물질인 aflatoxin $\mathrm{B}_{1}\left(\mathrm{AFB}_{1}\right)$ 과 직접 돌연변이원인 $\mathrm{N}$-methyl-N'-nitroN-nitrosoguamidine (MNNG)은 Sigma Chemical Co. (St. Louis, $\mathrm{MO}, \mathrm{USA}$ )로부터 구입하였고 $\mathrm{AFB}_{1}$ 은 $\mathrm{DMSO}$ 에, $\mathrm{MNNG}$ 는 증류수에 녹여 실험에 사용하였다. 간접돌연변이원 인 $\mathrm{AFB}_{1}$ 의 경우 활성화를 위하여 Maron과 Ames의 방법[13] 에 따라 S9 mixture를 첨가하였다. 항돌연변이 실험은 미리 건열 멸균시킨 glass cap tube에 S9 mix 혹은 phosphate buffered saline (PBS) $0.5 \mathrm{ml}$, 하룻밤 배양된 균주 $0.1 \mathrm{ml} \mathrm{(1} \mathrm{2 \times}$

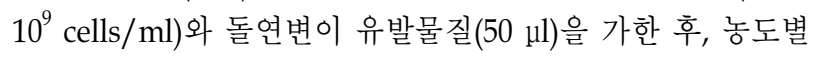
시료 $\left(1.25,2.5,5 \mathrm{mg} /\right.$ plate) $0.1 \mathrm{ml}$ 를 가하여 $37^{\circ} \mathrm{C}$ 에서 20 분간 예비 배양한 다음 histidine/biotin이 첨가된 top agar $\left(45^{\circ} \mathrm{C}\right)$ $2 \mathrm{ml}$ 씩을 가하고 vortex하여 minimal glucose agar plate에 도말하고 $37^{\circ} \mathrm{C}$ 에서 48 시간 배양한 후 revertant 숫자를 계수하 였다. 돌연변이 억제효과의 정도(inhibition rate)는 아래식에 의해 계산하였다[1].

$$
\text { Inhibition rate }(\%)=[(a-b) /(a-c)] \times 100
$$

여기서 $\mathrm{a}$ 는 돌연변이원에 의해 유도된 복귀돌연변이원 수, $\mathrm{b}$ 는 시료를 처리하였을 때의 복귀돌연변이의 수이며, $\mathrm{c}$ 는 돌연변이원과 시료가 없을 경우의 자연복귀돌연변이원 의 수이다.

\section{암세포 배양 및 증식 억제 실험}

한국 세포주 은행(서울의대)으로부터 인체 위암세포(AGS),
인체 결장암세포(HT-29) 및 인체 간암세포(Hep 3B)를 분양받 아 본 실험실에서 배양하면서 실험에 사용하였다. 인체 암세 포를 100 units $/ \mathrm{ml}$ 의 penicillin-streptomycin과 $10 \%$ fetal calf serum (FCS)가 함유된 DMEM 배지를 사용하여 $37^{\circ} \mathrm{C}, 5 \% \mathrm{CO}_{2}$ incubator에서 배양하였다. 배양 중인 세포를 1주일에 2번 refeeding하고 1주일 후 PBS로 세척한 뒤 $0.05 \%$ trypsin- $0.02 \%$ EDTA (Gibco Co., USA)로 부착된 세포를 분리하여 원심분리 한 후 집적된 암세포에 배지를 넣고 피펫으로 암세포가 골고 루 분산되도록 잘 혼합하여 $75 \mathrm{~mm}^{3}$ cell culture flask에 10 $\mathrm{ml}$ 씩 일정수 분할하여 주입하고 계속 6 7일마다 계대 배양하 면서 실험에 사용하였다. 계대 배양 시 각각의 passage number를 기록하였고 passage number가 10회 이상일 때는 새로 운 암세포를 액체 질소 탱크로부터 꺼내어 다시 배양하여 실 험하였다. 암세포 증식 억제 실험은 암세포 배양과 동일한 방 법으로 배양하되 원심분리 한 후 집적된 암세포를 골고루 분 산되도록 잘 혼합하여 24-well plate에 20,000 cells/ml의 농도 를 seeding하여 하룻밤 배양하였다. 각 시료 메탄올 추출물 $(1$ $\mathrm{mg} / \mathrm{ml}$ )을 $10 \mu \mathrm{l} / \mathrm{ml}$ medium에 첨가하여 2일 마다 배지로 교 체해서 배양 6 일 후에 증식된 세포를 $0.05 \%$ trypsin- $0.02 \%$ EDTA로 분리하여 각 세포수를 hemocytometer로 측정하여 대조군과 비교하여 암세포 성장 억제효과를 관찰하였다[4,6].

\section{통계분석}

실험결과는 mean $\pm \mathrm{SD}$ 으로 나타내었고 분석된 실험 데이터 는 대조군과 각 시료로부터 얻은 실험 자료로부터 one-way ANOVA를 실시하여 유의성이 있을 경우에 post-hoc test로 Duncan's multiple range test를 실시하여 95\% 수준에서 유의 성을 검증하였다.

\section{결과 및 고찰}

\section{콩 종류별 항돌연변이 효과 비교}

선행연구에서 대두를 먼저 헥산으로 지방을 제거한 후 메탄 올로 추출한 후 얻어진 메탄올 추출물에 의한 항돌연변이 효 과를 검토한 결과 $\mathrm{AFB}_{1}$ 에 대해서는 $37 \%$ 그리고 $\mathrm{MNNG}$ 에 대 해서는 $43 \%$ 의 저해효과를 나타내었고 메탄올 추출물을 극성 이 다른 용매인 디클로로메탄, 에틸아세테이트 및 부탄올로 분획하여 얻어진 각 분획물들에 의한 항돌연변이 효과를 검토 한 결과 $\mathrm{AFB}_{1}$ 에 대해 클로로메탄 및 에틸아세테이트 분획물 들은 $80 \%$ 이상의 저해효과를 나타내었음을 보고하였다[11]. 이에 본 연구에서는 대두와 함께 건강식품으로 각광받고 있는 검은콩을 종류별로 나누어 항돌연변이 효과를 비교하기 위하 여 식품을 포함하여 환경적인 요인에 의한 돌연변이 유발 물 질을 탐지하는데 널리 이용되는 Ames test를 실시하였다. 간 접돌연변이원인 $\mathrm{AFB}_{1}(0.7 \mu \mathrm{g} / \mathrm{plate})$ 에 대해 모든 종류의 콩 메탄올 추출물들은 농도의 증가와 더불어 돌연변이 억제 효과 
가 증가하였다(Table 1). 대두 메탄올 추출물보다는 검정콩들 인 흑태, 서목태 및 서리태 메탄올 추출물에 의한 효과가 높은 경향을 나타내었다. 검정콩 메탄올 추출물들은 첨가농도 1.25 $\mathrm{mg} /$ plate일 때부터 활성이 나타나 $5 \mathrm{mg} / \mathrm{plate}$ 일 때 $70 \%$ 이상 의 돌연변이 억제 효과를 나타내었다. 검정콩 중에서 약콩이 라고 불리는 서목태에 의한 항돌연변이 효과가 높아 첨가농도 $5 \mathrm{mg} /$ plate일 때 $82 \%$ 의 효과를 나타내었다. MNNG은 S. typhimurium TA100에 대한 대표적인 diagnostic mutagen으로 서 이들의 활성화에 S9 activation를 필요로 하지 않는 직접 돌연변이원이다[25]. MNNG $0.5 \mathrm{\mu g} / \mathrm{plate}$ 의 농도를 사용하여 S. typhimurium TA100 균주에 대한 각 종 콩 메탄올 추출물들 의 항돌연변이성 실험을 한 결과, 대두 메탄올 추출물에 의한 돌연변이 억제 효과는 미미하였고 검정콩 메탄올 추출물들에 의한 효과가 높았음을 살펴 볼 수가 있었다(Table 2). $\mathrm{AFB}_{1}$ 에 대한 효과와 유사하게 검정콩 중 서목태에 의한 효과가 높았 으며 첨가농도 2.5 및 $5 \mathrm{mg} /$ plate일 때부터 각각 $58 \%$ 및 $61 \%$ 로 돌연변이를 억제시켰다. 첨가농도 $5 \mathrm{mg} / \mathrm{plate}$ 일 때 흑태 및 서리태 메탄올 추출물들은 각각 $51 \%$ 및 $53 \%$ 의 효과를 나타 냄을 살펴볼 수가 있었다. 이상의 결과에서 S. typhimurium $\mathrm{TA} 100$ 균주에 대한 $\mathrm{AFB}_{1}$ 과 $\mathrm{MNNG}$ 의 돌연변이 유발실험에 서 각종 콩 메탄올 추출물들은 직접돌연변이원에 대해서

Table 1. Effect of methanol extracts from various soybeans on the mutagenicity of $\mathrm{AFB}_{1}(0.7 \mathrm{\mu g} /$ plate $)$ in Salmonella typhimurium TA100 ${ }^{1}$

\begin{tabular}{lccc}
\hline \multicolumn{2}{c}{ Sample (mg/plate) } & $\begin{array}{c}\text { Revertants/ } \\
\text { plate }\end{array}$ & $\begin{array}{c}\text { Inhibition } \\
\text { rate }(\%)^{2}\end{array}$ \\
\hline Spontaenous & & $128 \pm 13^{3}$ & \\
Control (AFB $\left.{ }^{1}\right)$ & & $986 \pm 156^{\mathrm{a}}$ & \\
Yellow soybean & 1.25 & $571 \pm 161^{\mathrm{b}}$ & 48 \\
& 2.5 & $493 \pm 55^{\mathrm{c}}$ & 57 \\
Black soybean & 5 & $475 \pm 32^{\mathrm{c}}$ & 60 \\
& 1.25 & $547 \pm 32^{\mathrm{b}}$ & 51 \\
Seomoktae & 2.5 & $448 \pm 80^{\mathrm{c}}$ & 63 \\
& 5 & $365 \pm 73^{\mathrm{c}}$ & 72 \\
& 1.25 & $481 \pm 58^{\mathrm{c}}$ & 59 \\
Seoritae & 2.5 & $386 \pm 54^{\mathrm{c}}$ & 70 \\
& 5 & $281 \pm 56^{\mathrm{d}}$ & 82 \\
& 1.25 & $534 \pm 131^{\mathrm{b}}$ & 53 \\
& 2.5 & $439 \pm 111^{\mathrm{c}}$ & 64 \\
& 5 & $339 \pm 25^{\mathrm{c}}$ & 75 \\
\hline
\end{tabular}

${ }^{1} 0.5 \mathrm{ml}$ of $\mathrm{S} 9 \mathrm{mix}, 0.1 \mathrm{ml}$ of the test bacterial suspension from an overnight culture, $50 \mu \mathrm{l}$ of $\mathrm{AFB}_{1}$ and $0.1 \mathrm{ml}$ of the test compound were added. Then the plates were incubated at $37^{\circ} \mathrm{C}$ for $48 \mathrm{hr}$. and the revertant bacterial colonies on each plate were counted.

${ }^{2}$ Inhibition rate $(\%)=($ Control-Sample $) /($ Control-Spontaneous $) \times$ 100

${ }^{3}$ Values are mean \pm SD. ${ }^{\text {a-d }}$ Values with different letters are significantly different at $p<0.05$.
Table 2. Effect of methanol extracts from various soybeans on the mutagenicity of MNNG $(0.5 \mu \mathrm{g} /$ plate $)$ in Salmonella typhimurium $\mathrm{TA}^{1} 100^{1}$

\begin{tabular}{lccc}
\hline \multicolumn{2}{c}{ Sample (mg/plate) } & $\begin{array}{c}\text { Revertants/ } \\
\text { plate }\end{array}$ & $\begin{array}{c}\text { Inhibition } \\
\text { rate }(\%)^{2}\end{array}$ \\
\hline Spontaenous & & $165 \pm 38^{3}$ & \\
Control (MNNG) & $1891 \pm 31^{\mathrm{a}}$ & \\
Yellow soybean & 1.25 & $1237 \pm 153^{\mathrm{b}}$ & 38 \\
& 2.5 & $1142 \pm 89^{\mathrm{c}}$ & 43 \\
Black soybean & 5 & $1108 \pm 115^{\mathrm{c}}$ & 45 \\
& 1.25 & $1387 \pm 118^{\mathrm{b}}$ & 29 \\
& 2.5 & $1271 \pm 114^{\mathrm{b}}$ & 36 \\
Seomoktae & 5 & $1016 \pm 100^{\mathrm{c}}$ & 51 \\
& 1.25 & $1047 \pm 160^{\mathrm{c}}$ & 49 \\
Seoritae & 2.5 & $887 \pm 77^{\mathrm{d}}$ & 58 \\
& 5 & $840 \pm 199^{\mathrm{d}}$ & 61 \\
& 1.25 & $1280 \pm 42^{\mathrm{b}}$ & 35 \\
& 2.5 & $1209 \pm 305^{\mathrm{b}}$ & 40 \\
\hline
\end{tabular}

${ }^{1} 0.5 \mathrm{ml}$ of PBS, $0.1 \mathrm{ml}$ of the test bacterial suspension from an overnight culture, $50 \mu \mathrm{l}$ of MNNG and $0.1 \mathrm{ml}$ of the test compound were added. Then the plates were incubated at $37^{\circ} \mathrm{C}$ for $48 \mathrm{hr}$. and the revertant bacterial colonies on each plate were counted.

${ }^{2}$ Inhibition rate $(\%)=($ Control-Sample $) /($ Control-Spontaneous $) \times$ 100

${ }^{3}$ Values are mean \pm SD. ${ }^{\text {a-d }}$ Values with different letters are significantly different at $p<0.05$.

보다는 간접돌연변이원에 의해 유발된 돌연변이 저해에 더 효과적이었으며 대두보다 검정콩에 의한 항돌연변이 효과가 더 우수하였음을 관찰할 수가 있었다. 노란콩을 주축으로 한 항돌연변이 효과에 대한 연구는 알려져 있으나 검은콩 및 검 은콩을 이용한 발효식품에 대한 항돌연변이 연구는 아직 미진 한 상태이다.

\section{암세포 증식 억제효과 비교}

인체 암세포를 이용하여 대두 및 검정콩 메탄올 추출물들에 의한 암세포 증식 억제 효과를 검토한 결과, 모든 종류의 콩 메탄올 추출물(첨가농도 $1 \mathrm{mg} / \mathrm{ml}$ )을 인체 위암세포(AGS)에 처리했을 때 $50 \%$ 이상의 암세포 증식 억제 효과를 나타내었다 (Fig. 1). 대두보다는 검정콩에 의한 효과가 높았으며 흑태, 서 목태 및 서리태 메탄올 추출물은 각각 $61 \%, 70 \%$ 및 $65 \%$ 의 암세포 증식 억제효과를 나타내었다. Fig. 2는 인체 결장암세 포(HT-29)에 이들 콩 메탄올 추출물들을 처리했을 때 암세포 증식 억제 효과를 나타낸 것으로 인체 위암세포에 처리했을 때처럼 검정콩 메탄올 추출물에 의한 효과가 대두보다 높은 경향을 나타내었으나 서목태 메탄올 추출물을 제외하고는 유 의적 차이는 살펴 볼 수가 없었다. 서목태 메탄올 추출물은 $69 \%$ 의 암세포 증식억제 효과를 나타내었다 $(\mathrm{p}<0.05)$. 인체 간 


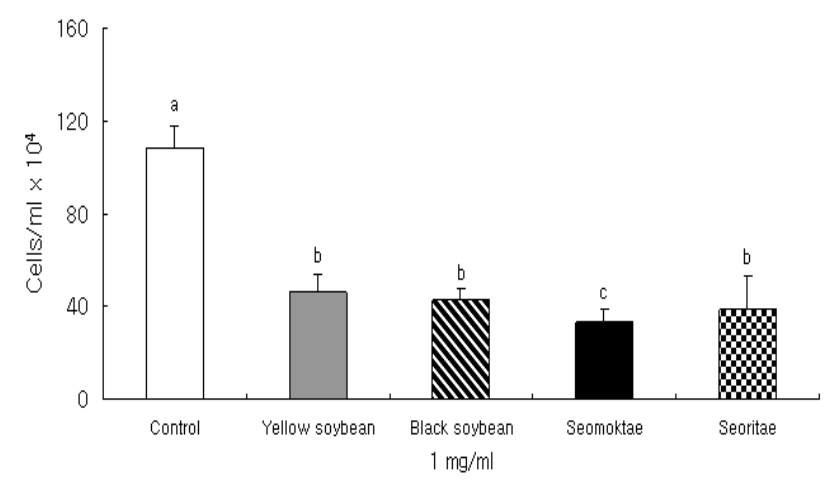

Fig. 1. Inhibitory effect of methanol extracts of various soybeans on the growth of AGS human gastric adenocarcinoma cells. ${ }^{\text {a-c } V a l u e s ~ w i t h ~ d i f f e r e n t ~ l e t t e r s ~ a r e ~ s i g n i f i c a n t l y ~}$ different at $p<0.05$.

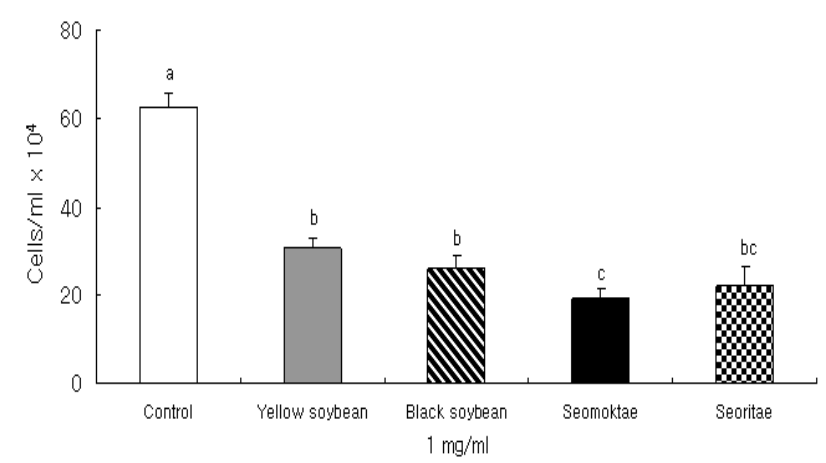

Fig. 2. Inhibitory effect of methanol extracts of various soybeans on the growth of HT-29 human colon adenocarcinoma cells. ${ }^{a-c}$ Values with different letters are significantly different at $p<0.05$.

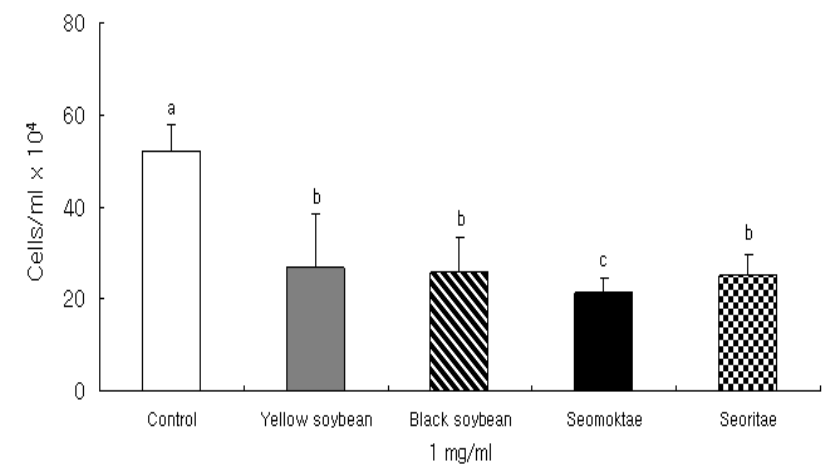

Fig. 3. Inhibitory effect of methanol extracts of various soybeans on the growth of Hep 3B human hepatocellular carcinoma cells. ${ }^{\mathrm{a}-\mathrm{c}}$ Values with different letters are significantly different at $p<0.05$

암세포(Hep 3B)에 의한 증식 억제효과는 이상의 암세포에 대 한 효과보다 다소 낮았으나 흑태, 서목태 및 서리태 메탄올 추출물은 첨가농도 $1 \mathrm{mg} / \mathrm{ml}$ 에서 각각 $51 \%, 59 \%$ 및 $52 \%$ 의 저해효과를 나타내어 여기서도 서목태에 의한 억제효과가 높
았다(Fig. 3). $\operatorname{Lim}$ 등[12]은 노란콩과 검정콩의 메탄올 추출물 과 각각의 콩으로부터 제조된 된장 메탄올 추출물이 interleukin-2 (IL-2), interleukin-6 (IL-6) 및 tumor necrosis factor-a (TNF-a)를 포함하는 사이토카인의 생성에 미치는 영향을 검 토한 결과 검정콩 발효식품에서 IL-2, IL-6 및 TNF-a 생성이 높았으며 암세포 증식 억제효과는 이들 사이토카인 생성 증진 에 따른 면역 담당 세포 활성화 작용과 관련이 있을 것으로 보고하였다. 또한 종양전이의 예방적 효과에 대한 실험에서 7 개월 발효된 검정콩 된장에서 종양전이를 크게 억제하는 것 으로 나타내었다고 보고하였다. 검정콩은 암세포가 면역시스 템에 의한 공격을 피해 살아남을 수 있게 도와주는 heat shock protein, glucose-related protein과 같은 스트레스 단백질 생성 을 저해함으로써 유방암, 직장암 및 전립선암 등에 항암작용 을 나타내는 것으로 보고되었다[23,24]. Bae와 Moon [2]은 노 란콩, 대립 검정콩 및 소립 검정콩의 anthocyanin 색소 및 총 페놀 함량을 측정한 결과 소립 검정콩, 대립 검정콩 및 노란콩 의 순으로 그 함량이 많았으며 이들 콩에 대한 항산화 효과는 anthocyanin 색소 및 총 페놀 함량에 비례하여 높게 나타났다 고 보고하였다. Shon 등[17]은 대두 청국장보다 검정콩 청국장 의 isoflaovone 함량이 많은 이유로서 검정콩 자체에 함유한 isoflavone 함량이 더 많았다고 보고하였다. Kim 등[7]은 검정 콩에 함유되어 있는 주요 생리활성 물질들인 isoflavone, tocopherol, phenolic acids 및 anthocyanin의 항산화 효과를 측정 한 결과 genistein, genistic acid 및 tocophenol 및 anthocyanin 의 항산화 효과가 높은 것으로 나타났다고 보고하였다. 또한 네 종류의 항산화 물질들의 시너지 효과를 분석한 결과 이들 은 서로 시너지 효과가 있는 것으로 나타났으며 특히 anthocyanin을 혼합할 때 시너지 효과가 가장 높게 나타나 검은콩의 항산화 효과에 anthocyanin이 크게 관여하는 것으로 보고하 였다. 검은콩을 대상으로 한 연구는 주로 항산화 활성에 관한 연구가 주를 이루며 우리나라 토종 콩인 서목태에 대한 연구 는 Shin과 Han [18]에 의한 연구를 제외하고는 거의 찾아 볼 수가 없다. 이들 연구는 서목태 추출물군이 고콜레스테롤과 고지방 식이에 의한 혈중 지질 감소효과를 나타내었고 동맥경 화지수도 서목태 추출물을 병합 급여하지 않는 고콜레스테롤 식이에 지방 및 고지방 병합 급여군은 5.0-8.4인데 비하여 서목 태 추출물 농도를 달리한 고지방 및 고콜레스테롤 병합 식이 급여군이 2.3-4.5로 농도가 높을수록 유의적으로 동맥경화지 수가 감소하였다고 보고하였다. 본 연구의 결과로부터 Ames test를 이용한 항돌연변이 실험에서 검정콩 메탄올 추출물에 의한 돌연변이 억제 효과가 높았고 in vitro 암세포 증식 억제 효과에서도 대두보다는 검은콩 메탄올 추출물에 의한 항암활 성이 더 우수한 것으로 나타났으며 특히 소립 검정콩에 해당 하는 서목태에 의한 생리활성이 우수하였으므로 검정콩에 많 이 함유된 색소에 의한 효과라고 추정되며 여기에 대한 향후 연구가 필요하다. 


\section{References}

1. Ames, B. N., J. McGann, and E. Yamasaki. 1975. Method for detecting carcinogens and mutagens with the Salmonellsa/ mammalian-microsome mutagenicity test. Muta. Res. 31, 347-364.

2. Bae, E. A. and G. S. Moon. 1997. A study on the antioxidative activities of Korean soybeans. J. Korean Soc. Food Sci. Nutr. 26, 203-208.

3. Choi, S. H. and Y. A. Ji. 1989. Changes in flavor chungkookjang during fermentation. Korean J. Food Sci. Technol. 21, 229-234

4. Franceschi, R. T., W. M. James, and G. Zerlauth. 1985. 1a, 25-dihydroxy vitamin D3 specific regulation of growth, morphology and fibronectin and a human osteosarcoma cell line. J. Cell Physiol. 123, 401-409.

5. Francis, F. J. 1984. Future trends, pp. 233-247. In Walford, J. (ed.), Developments in Food Colors-2, Applied Science Publishers, New York, USA.

6. Goldburg, E., H. Nitowsky, and S. Colowick. 1965. The role of glycolysis in the growth of tumor cells. J. Biol. Chem. 240, 2791-2796.

7. Kim, S. H., T. W. Kwon, Y. S. Lee, M. G. Choung, and G. S. Moon. 2005. A major antioxidative components and comparison of antioxidative activities in black soybean. Korean J. Food Sci. Technol. 37, 73-77.

8. Kim, Y. H., H. T. Yun, K, Y, Park, and S. D. Kim. 1997. Extraction and separation of anthocyanins in black soybeans. RDA J. Crop. Sci. 39, 35-38.

9. Koh, K. J., D. B. Shin, and Y. C. Lee. 1997. Physicoshemical properties of aqueous extraction from small red bean, mung bean and black soybean. Korean J. Food Sci. Technol. 29, 854-859.

10. Liao, H. F., C. J. Cou, S. H. Wu, K. H. Khoo, C. F. Chen, and S. Y. Wang. 2001. Isolation and characterization of an active compound from black soybean [Glycine max (L.) Merr] and its effect on proliferation and differentiation of human leukemic U937 cells. Anti-Cancer Drugs 12, 841-846.

11. Lim, S. Y. 2007. Antimutagenicity and anticancer activity of soybean fractions extracted by solvents. J. Life Sci. 17, 1368-1373.

12. Lim, S. Y., K. Y. Park, M. S. Bae, and K. H. Kim. 2009. Effect of doenjang with black soybean on cytokine production and inhibition of tumor metastasis. J. Life Sci. 19, 264-270.

13. Maron, D. M. and B. N. Ames. 1983. Reversed methods for the Salmonella mutagenicity test. Muta. Res. 113, 173-215.

14. Pratt, D. E. and P. M. Birac. 1979. Sources of antioxidant activity of soybean and soy products. J. Food Sci. 44, 1720-1725.

15. Record, I. R., I. E. Dreosit, and J. K. Mclnerney. 1995. The antioxidant activity of genistein in vitro. J. Nutr. Biochem. 6, 481-485.

16. Ryu, S. H. and G. S. Moon. 2003. Antioxidative and antiaging effects of dietary yellow and black soybean in rats. J. Korean Soc. Food Sci. Nutr. 32, 591-597.

17. Shin, M. K. and S. H. Han. 2002. Effect of soybean extracts on serum lipid concentrations in fat diets fed rats. Korean Soyeban Digest 19, 48-54.

18. Shin, M. K. and S. H. Han. 2002. Effect of methanol extracts from Rhynchosia nulubillis on serum lipid concentrations in rats fed high fat and high cholesterol diet. Korean J. Dietary Culture 17, 64-69.

19. Shon, M. Y., K. I. Seo, S. W. Lee, S. H. Choi, and N. J. Sung. Biological activities of chungkugjang prepared with black bean and changes in phytoestrogen content during fermentation. Korean J. Food Sci. Technol. 32, 936-941.

20. Son, J. H., M. G. Chung, H. J. Choi, U. B. Jang, G. M. Son, M. W. Byun, and C. Choi. 2001. Physiological effect of Korean black soybean pigment. Korean J. Food Sci. Technol. 33, 764-768.

21. Son, J. H., M. G. Chung, H. J. Choi, U. B. Jang, J. H. Bae, H. D. Lee, and C. Choi. 2002. Stability of black soybean pigment extract. J. Korean Soc. Agric. Chem. Biotechnol. 45, 179-184.

22. Tsuda, T., K. Shiga, K. Oshima, S. Kawakishi, and T. Osawa. 1996. Inhibition of lipid peroxidation and the active oxygen isolated from Phaselous vulgaris L. Biochem. Pharmacol. 52, 1033-1039.

23. Wei, H., L. Wei, K. Frenkel, R. Browen, and S. Barnes. 1993. Inhibition of tumor promotor-induced hydrogen peroxide formation in vitro and in vivo by genistein. Nutr. Cancner 20, 1-5.

24. Wei, H., Q. Cai, and R. Rahn. 1996. Inhibition of UV lightand Fenton reaction-induced oxidative DNA damage by the soybean isoflavone genistein. Carcinogenesis 17, 73-78.

25. Zaidi, N. H., P. J. O'Connor, and W. H. Butler. 1993. N-methyl-N'-nitro-N-nitrodoguamidine-induced carcinogenesis: differential pattern of upper gastointestinal tract tumours in Wistar rats after single or chronic oral doses. Carginogenesis 14, 1561-1567. 


\section{초록 : 콩 종류별 항돌연변이 및 암세포 증식 억제 효과 비교}

\section{임 선 영*}

(한국해양대학교 해양환경생명과학부)

본 연구에서는 대두와 검정콩에 속하는 흑태, 서목태 및 서리태의 항돌연변이 및 암세포 증식 억제 활성을 비 교하였다. Ames test를 이용한 항돌연변이 실험에서 간접돌연변이원인 $\mathrm{AFB}_{1}$ 에 대해 모든 종류의 콩 메탄올 추출 물들은 농도 의존적으로 돌연변이 억제 효과가 증가하였다 $(\mathrm{p}<0.05)$. 대두 메탄올 추출물보다는 검정콩들인 흑태, 서목태 및 서리태 메탄올 추출물에 의한 효과가 높은 경향을 나타내었다. 검정콩 중에서 약콩이라고 불리는 서목 태에 의한 항돌연변이 효과가 높아 첨가농도 $5 \mathrm{mg} / \mathrm{plate}$ 일 때 $82 \%$ 의 효과를 나타내었다. 직접 돌연변이원인 MNNG에 대한 각 종 콩 메탄올 추출물들의 항돌연변이성 실험을 한 결과, $\mathrm{AFB}_{1}$ 에 대한 효과와 유사하게 검정콩 중 서목태에 의한 효과가 높았으며 첨가농도 2.5 및 $5 \mathrm{mg} / \mathrm{plate}$ 일 때부터 각각 $58 \%$ 및 $61 \%$ 로 돌연변이를 억제시 켰다. 인체 암세포를 이용하여 대두 및 검정콩 메탄올 추출물들에 의한 암세포 증식 억제 효과를 검토한 결과, 모든 종류의 콩 메탄올 추출물(첨가농도 $1 \mathrm{mg} / \mathrm{ml}$ )을 인체 위암세포 $(\mathrm{AGS})$ 에 처리했을 때 $50 \%$ 이상의 암세포 증 식 억제 효과를 나타내었고 대두보다는 검정콩에 의한 효과가 높았으며 흑태, 서목태 및 서리태 메탄올 추출물은 각각 $61 \%, 70 \%$ 및 $65 \%$ 의 암세포 증식 억제효과를 나타내었다. 인체 결장암세포(HT-29)의 경우, 검정콩 메탄올 추출물에 의한 효과가 대두보다 높은 경향을 나타내었으나 서목태 메탄올 추출물을 제외하고는 유의적 차이는 살펴 볼 수가 없었다. 인체 간암세포( $\mathrm{Hep} 3 \mathrm{~B})$ 에 의한 증식 억제효과는 이상의 암세포에 대한 효과보다 다소 낮았 으나 흑태, 서목태 및 서리태 메탄올 추출물은 첨가농도 $1 \mathrm{mg} / \mathrm{ml}$ 에서 각각 $51 \%, 59 \%$ 및 $52 \%$ 의 저해효과를 나타 내어 여기서도 서목태에 의한 억제효과가 높았다. 따라서 본 연구의 결과로부터 Ames test를 이용한 항돌연변이 및 인체 암세포 증식 억제 실험에서 검정콩 메탄올 추출물에 의한 억제 효과가 높았고 특히 소립 검정콩에 해당 하는 서목태에 의한 생리활성이 우수하였으므로 검정콩에 많이 함유된 색소에 의한 효과라고 추정되며 여기에 대한 향후 연구가 필요하다. 